\title{
(CO)EXISTÊNCIAS NÔMADES: TRASLADOS POÉTICOS EM REDES NARRATIVAS
}

\author{
Fernanda Maria Macahiba Massagardi ${ }^{1}$ \\ Isto sabemos. \\ todas as coisas estão ligadas \\ como o sangue \\ que une uma família...
}

Tudo o que acontece com a Terra, acontece com os filhos e filhas da Terra.

O homem não tece a teia da vida; ele é apenas um fio. Tudo o que faz à teia, ele faz a si mesmo.

Ted Perry ${ }^{2}$

\section{O Projeto Imágenes Viajeras}

Iniciado na cidade de Jaen, Espanha, no ano de 2014, o projeto Imágenes Viajeras fez seu translado pelo Atlântico, aportando no Brasil no ano de 2015.

A partir de reproduções fotográficas em tamanho A3, cuja temática é "Caminhos", de autoria de Carmen Molina e Alfonso Infantes, foram realizadas intervenções com materiais diversos. Tais registros fotográficos foram suporte para uma criação coletiva e comunitária (no sentido ideal de comunidade proposto por Bauman). Tal proposta dialoga com Canton, que afirma:

Como resposta, no decorrer do tempo, em especial a partir da década de 1980, muitos artistas sentem necessidade de se reaproximar da realidade e do público e retomam a ideia de narrativa. Eles passam a buscar uma produção que se relacione diretamente com os fatos e movimentos da vida e deixam de se colocar numa posição transcendente, na qual a arte poderia se valer por si mesma, descolada dos limites impostos pela vida real. (CANTON, 2009a, p. 26-27)

O propósito desta pesquisa foi relacionar metaforicamente a intervenção artística aos caminhos da própria existência humana. Dessa forma, as imagens realizadas por uma artista, numa ação nômade, deslancharam seus caminhos por muitas outras mãos, não condicionadas apenas a uma vontade criadora, mas influenciadas por todos aqueles que deixaram algum vestígio de sua história em forma de concretude material. Assim, no translado, muitas vezes perdiam-se as pistas ou, em alguns casos, elas eram encontradas e ressignificadas por outrem. Lins afirma:

É no prolongamento da filosofia nietzschiana que se pode desenvolver a ideia de "sujeito nômade", cuja subjetividade se desenvolve como meio caminho entre suas pulsões inconscientes e as determinações culturais, em um lugar de contradições que escapa à consciência e a sua razão. O sujeito nômade é uma

\footnotetext{
${ }^{1}$ Pós-doutora em Artes pela Universidade Estadual de Campinas. Professora do Centro Universitário Cruzeiro do Sul. E-mail: nandamacahiba@gmail.com.

2 Paráfrase de carta de um Chefe Seatle para os americanos. Disponível em: <http://www.desenredo.com.br/Textos/CartaChefeSeattle.htm>. Acesso em: 30 out. 2017.
} 
imagem performativa que se distingue do modo de pensar dominante, agente político - aquele que age - que remete a um desejo intenso de transgredir as fronteiras e estender os limites [...] (LINS, 2014, p. 140).

Assim, este projeto é uma ação performática e narrativa, no sentido estabelecido por Lins (2012), e desvendou trajetórias múltiplas e surpreendentes, transgredindo fronteiras e estendendo possibilidades. As imagens transitaram, ganhando substância a partir de marcas, cortes, respiros, sofrimento, cores, como avatares da própria existência humana.

Também é importante ressaltar o caráter lúdico da proposta e a singularidade de cada participante que, somada às outras, geraram imagens singulares, coletivas e significativas.

A atividade lúdica [...] não é encontrada nos prazeres estereotipados, no que é dado pronto, pois estes não possuem a marca da singularidade do sujeito que a vivencia, que a preenche de significados. (PEREIRA, 2011, p. 61)

Dessa forma, várias narrativas foram sobrepostas às outras, gerando um território híbrido de existências que (co)existem em uma mesma época e contexto. Território este que revela questões, mas não necessariamente dá resposta objetiva à malha criada por tantos. Nesse sentido, a afirmação de Canton, (2009a) sobre as narrativas contemporâneas, acorda com a proposta, ao ensinar que:

As narrativas enviesadas contemporâneas também contam histórias, mas de modo não linear. No lugar do começo-meio-fim tradicional, elas se compõem a partir de tempos fragmentados, sobreposições, repetições, deslocamentos. Elas narram, porém não necessariamente resolvem as próprias tramas (CANTON, 2009a, p. 15).

As marcas surgidas pelas intervenções múltiplas apresentam suas particularidades, que foram criadas a partir de um mesmo marco. Na Espanha, mais de duzentas pessoas fizeram intervenções nas imagens. No Brasil, este número chegou a trezentos. Seres de todas as idades, sensibilidades, profissões, expuseram sua forma particular de ver, criar, conectar com o que encontram pelo caminho. Em seguida, repassaram a algum grupo conhecido a imagem significada. Este, por sua vez, realizou a intervenção e novamente, numa proposta de nomadismo, encaminhou a obra modificada para nova intervenção. Anexo ao envelope com a imagem, uma lista para preenchimento de nome e endereço de $e$-mail para devolução.

Histórias de vida que se entrelaçaram, gerando um movimento concreto similar ao observado em redes, reunindo pessoas conhecidas e desconhecidas. Um movimento que demandou um processo perceptivo e seletivo, gerador de múltiplas interpretações e compreensões para que, a posteriori, fossem agregadas a ele novas marcas por meio da ação. Ostrower (2013, p. 57) alerta para o fato de que tais processos acontecem "a partir das condições físicas e psíquicas de cada pessoa, e ainda a partir de certas necessidades e expectativas.” De acordo com a autora:

Cabe entender a percepção como um processo altamente dinâmico e não como um mero registro mecânico de algum estímulo. "Dinâmico", no amplo sentido da palavra, de "forças em atividade". Nós participamos ativamente da percepção em vez de apenas estarmos passivamente presentes (OSTROWER, 2013, p. 57). 
No Brasil, algumas imagens migraram para um núcleo de artistas e educadores do Rio de Janeiro. Após a intervenção, uma das participantes encaminhou um e-mail para a autora deste artigo, desculpando-se antecipadamente pela não devolução de uma das reproduções. Segundo ela, vítima de uma doença degenerativa, há alguns anos não fazia trabalhos artísticos e, apesar da dor e quase total atrofia das mãos, por alguns dias interviu em uma das imagens já trabalhadas pelo grupo e quis guardar este momento em concretude, talvez o último, segundo ela, como artista.

$\mathrm{Na}$ Espanha, uma das imagens teve morada em um presídio. Recortes, remontagens, pinturas, marcas gráficas. Registro de pensamentos, como os de Maria Isabel:

a) La idea de romper no es siempre para destruir, muchas veces se rompe para volver a empezar. ${ }^{3}$

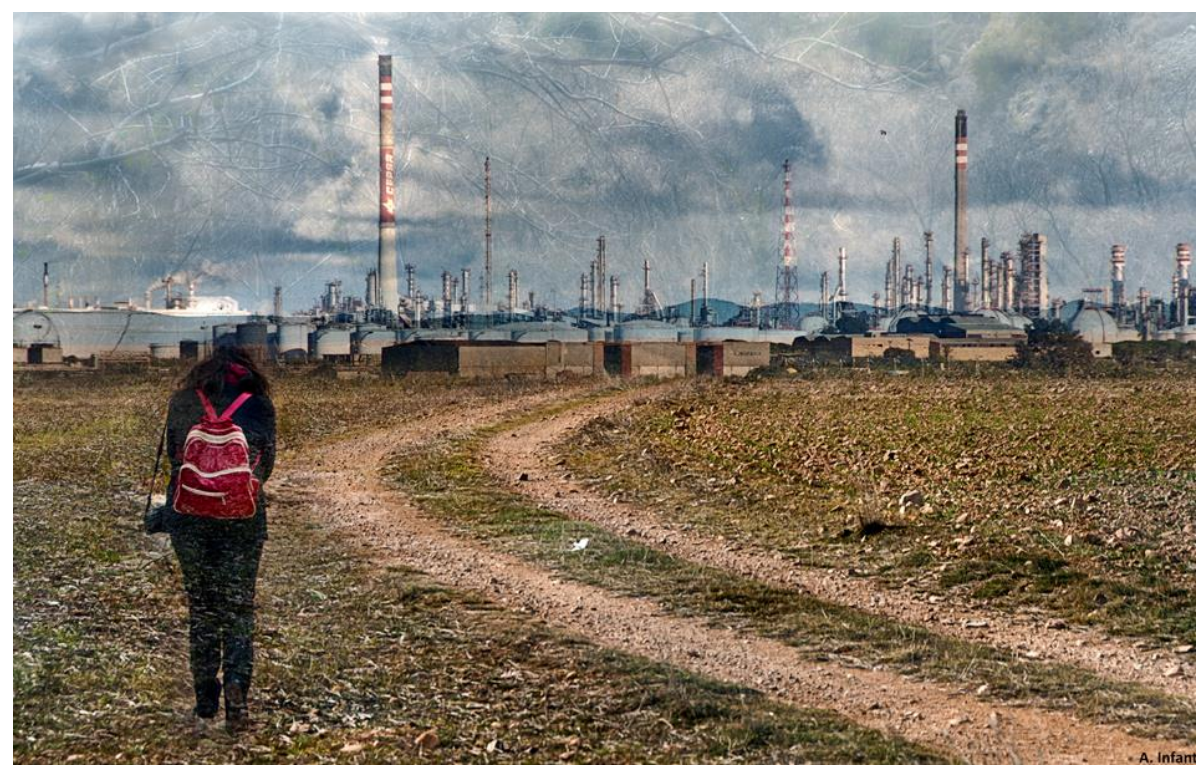

Fig. 1 - Fotografia de Carmen Molina. Fonte:

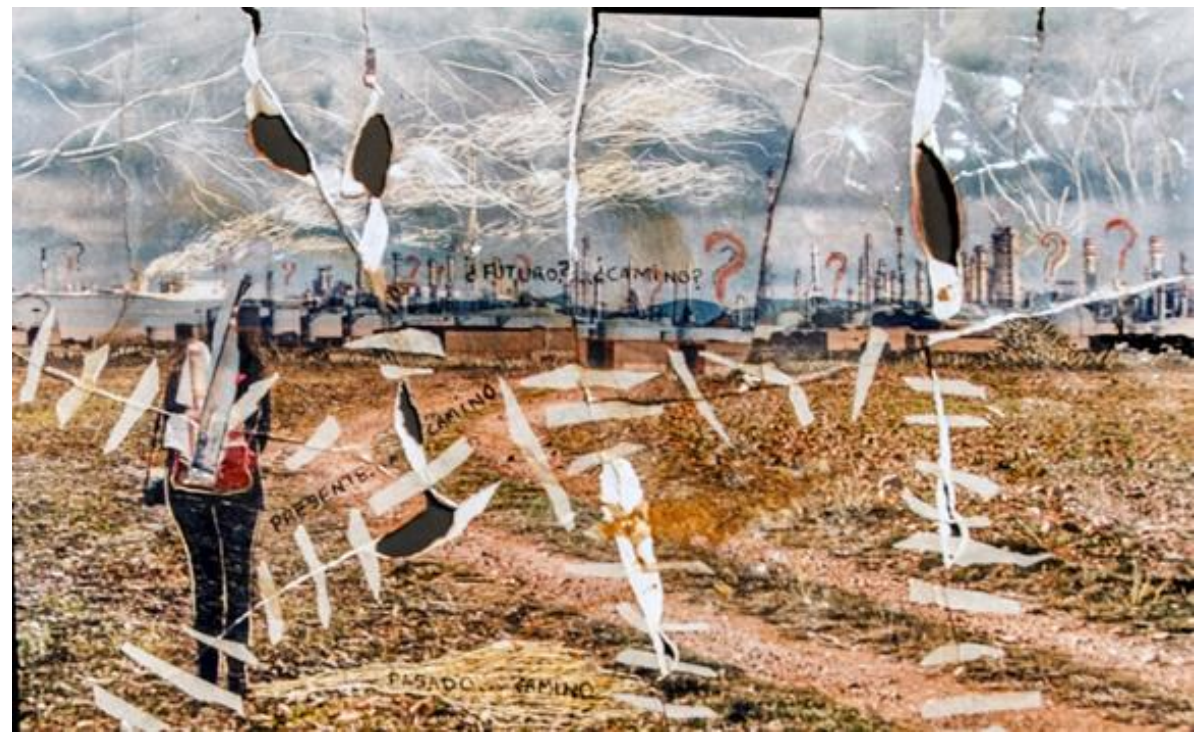

Fig. 2 - Intervenção do primeiro grupo. Fonte:

\footnotetext{
${ }^{3}$ A ideia de romper não é sempre para destruir, muitas vezes se rompe para voltar a começar.
} 
Estabelecida a possibilidade de ultrapassar fronteiras, foi possível adentrar na intimidade do outro por meio do acesso ao suporte que trazia marcas de vida em forma de matéria concreta. Zumthor explicita:

O acaso fez de mim um homem de fronteiras. Eu nasci, bem, há não poucos anos, a alguns quilômetros de uma entre algumas. Mas o que conta muito mais foi o número delas que eu secretamente atravessei ao longo desses anos. Fronteira, limite e separação; traço que demarca para cada um de nós o seu lugar e designa o domínio do Outro: no tempo, não menos que no espaço (ZUMTHOR, 1989, p. 7).

O fazer artístico não pode compactuar com a fronteira que separa, mas sim a que permite o trânsito para a diversidade que mora ao lado. Criar é ir além dos limites estabelecidos e não disponibilizar modelos estereotipados que aprisionam. Nesse sentido, a proposta aqui apresentada permite um fluxo contínuo e criativo para além dos limites geográficos e culturais dos países, indo no sentido contrário ao do sistema vigente, cujo " [...] controle veio se refinando ao ponto de procurar moldar as próprias personalidades dos indivíduos, desde o seu nascimento, bem como ter se tornado uma consciente preocupação operacional dos administradores das grandes corporações (DUARTE JÚNIOR, 2004, p. 73).

\section{A Matrix contemporânea}

Calvino (2001) relata, em um texto cujo narrador em primeira pessoa reforça a dimensão real da situação, a tomada de consciência de um homem que, num cruzamento (e esta é uma imagem de grande significação metafórica), em meio ao andar cotidiano, para e começa a rir daquilo que repentinamente observa de forma crítica: o movimento das pessoas e a aceitação plácida daquele mundo de semáforos, veículos, cartazes etc., que não fazia nenhum sentido. Então, após um riso incontido e ciência dos sentidos, chama os passantes em voz alta e alertaos para o fato de que aquele não era o caminho certo, que não levaria ninguém a lugar algum. Ansioso, ele luta por participá-los de sua descoberta, mas por eles é desmentido. Todos afirmam que tudo está no devido lugar, uma ação vinculada às outras, sem nenhum absurdo. Então, resignado, o homem sente-se perdido e, após a sensação de estar olhando o movimento do mundo de uma plateia, volta o olhar acrítico para a realidade que se apresenta e, repentinamente, tudo parece novamente natural. Ele pede desculpas, justificando que realmente deve ter havido algum equívoco em sua percepção, sob olhares severos.

Este conto de Calvino (2001) estabelece estrito diálogo com a teoria de Franco (2012). Segundo este último, em uma análise crítica de nossa estrutura social, em muitos nichos são observáveis grupos de pessoas que reproduzem padrões sem que se deem conta. De acordo com o autor "DE REPENTE UMA VENDA CAI DOS SEUS OLHOS e você vê: A Matrix. E você a vê em todo lugar: em casa, na escola, na igreja, na empresa, no comércio, em uma partida de futebol, no trânsito, nos locais de atendimento público, nas mídias sociais... (FRANCO, 2012, p. 10). Assim, o personagem de Calvino evoca uma realidade próxima e, infelizmente, se rende ao chamamento da maioria e reinsere sua 'padronagem' habitual, fazendo com que a grande máquina continue em movimento repetitivo e constante.

Franco (2012) exemplifica sua teoria com as redes virtuais, onde pessoas expõem e atuam em personagens que, na maioria das vezes, apresentam padrões como: frases de efeito, imagens estereotipadas e declarações pessoais de otimismo duvidoso. Tais ações geram avatares que são 'utilizados' em ocasiões determinadas e replicantes. Estas descrições incomodam muitos, talvez pela identidade que provocam. A tese apresentada é a de que, ao contrário do cenário do filme 
Matrix ${ }^{4}$, não há seres fora de nossa dimensão manipulando a realidade, mas nós mesmos, através de hierarquia e do poder por esta gerado, configuramos a Matrix e prolongamentos deste modelo. Assim, "organizações hierárquicas de seres humanos geram seres não-humanos. Mas alguma coisa impede que as pessoas vejam isso" (FRANCO, 2012, p. 13).

Também Ana Thomaz ${ }^{5}$, educadora e multiplicadora da técnica Alexander no Brasil, descreve a forma pela qual as pessoas reproduzem modelos em escolas, alegando que agem dessa forma seguindo ordens designadas por uma hierarquia. A pesquisadora percorre o caminho em busca do grande ditador de regras e descobre, ao chegar no topo da pirâmide, que o provável dono de tais regras não sabe a quem obedece. Entretanto, todos que estão abaixo dele seguem modelos que estão fundamentados em uma hierarquia superior que não sabe quem dita as ordens a ela. Franco esclarece:

As pessoas continuam reproduzindo comportamentos muito semelhantes que deformam o campo social - como se estivessem sob a influência de um mesmo sistema de crenças, valores, normas de comportamento e 17 padrões de organização; ou como se rodassem um programa básico que foi instalado em suas mentes e acham que o mundo (ou 'a realidade') é assim mesmo. Ora, isso evoca a metáfora do filme The Matrix, [...] as pessoas vão vivendo suas vidas, monótonas ou frenéticas, em suas modernas colmeias humanas, sem saber disso, tomando a aparência pela realidade (FRANCO, 2012, p. 16).

De acordo com a Franco (2012), estamos programados para obedecer a uma hierarquia que dita regras e, muitas vezes, neste movimento, "as pessoas não veem que seu comportamento replicante deforma o campo social. Elas acham que o mundo social só pode ser interpretado por meio de um conjunto de crenças básicas de referência" (FRANCO, 2012, p. 17). O grande malefício se dá quando essas aparentes verdades, tomadas por axiomas, deixam de despertar na população o interesse por validá-las ou não, a partir de reflexões.

Sair deste processo é possível, mas existe uma grande dificuldade, pois a Matrix exige comportamentos específicos das pessoas que desejam alcançar destaque, saindo do âmbito do "comum". Entretanto, é uma ilusão imaginar que ao apresentar certos diferenciais exigidos, estão fora do alcance da Matrix. Ao contrário:

Quando interagimos com alguém em qualquer ambiente hierárquico somos avaliados por esses diferenciais e começamos então a cultivá-los. Como reflexo dos fluxos verticais que passamos a valorizar, nossa vida também se verticaliza. É como se importássemos a anisotropia gerada no campo social pela hierarquia. Nessa ânsia de subir, começamos a imitar os de cima e a desprezar os de baixo. Ao fazer isso, porém, replicamos a Matrix (FRANCO, 2012, p. 79).

Neste movimento cíclico e replicante, tudo o que é singular parece perder o sentido ou visto como deformidade. O estereótipo avança e retrai-se a diversidade. Muitos afirmam que isso se dá devido à velocidade do cotidiano contemporâneo, que inviabiliza o tempo que seria destinado à uma educação da percepção. Por este motivo as relações em rede acontecem, cada dia mais, na superfície e não apenas na forma, mas também no conteúdo. A questão é: será possível estabelecer uma relação em rede de forma comunitária e solidária, onde a interação acrescente repertórios ricos e valorosos e não reproduza modelos?

\footnotetext{
${ }^{4}$ Matrix (1999) é uma produção do cinema estadunidense e australiano, dirigida pelas irmãs Wachowski. Gênero: ação e ficção científica.

${ }^{5}$ Disponível em: <https://www.youtube.com/watch?v=v70tmqKqmqA>. Acesso em: 8 de agosto de 2017.
} 


\section{As redes existenciais}

Num sentido lato é possível estabelecer inúmeras imagens e significações para o termo rede. Nossa existência, por exemplo, está interligada não apenas às pessoas, mas também ao ambiente em que vivemos, gerando uma rede relacional afetiva e espacial. Esta malha existencial implica em vivenciar as partes e o todo, de forma a perceber que cada ato repercute em formas e gera resultados. Não podemos desconsiderar a dimensão alcançada pelas possibilidades de conexão via internet.

Anteriormente, foi discutida a existência da Matrix segundo os preceitos de Franco (2012). Esta forma de tessitura pode produzir, por determinado tempo, uma falsa sensação de que tal modelo responde a um encadeamento significativo. Entretanto, é possível que, em algum momento, pessoas tenham a chance do despertar, como acontece no conto de Calvino, anteriormente descrito, gerando uma rede de caráter comunitário.

Este entrelaçamento de fios gera a malha invisível, que é constituída por partes que compõem um todo. Nesse sentido, a intervenção de um ponto interage com todos os outros pontos conectados. Cada elemento possuidor de sua história e circunstância existencial responde a esses estímulos, gerando realidades. Considerando o humano como agente e partes deste todo, é importante validar a multidimensionalidade que o compõe (ser biológico, psíquico, físico, social, afetivo e racional). Pascal afirma:

Sendo todas as coisas causadas e causadoras, ajudadas ou ajudantes mediatas e imediatas, e sustentando-se todas por um elo natural e insensível que une as mais distantes e as mais diferentes, considero ser impossível conhecer as partes sem conhecer o todo, tampouco conhecer o todo sem conhecer particularmente as partes (PASCAL, 1976, p. 35).

Um dos filmes de grande relevância que trata do referido tema, intitulado "Efeito Borboleta" ${ }^{6}$ ilustra, entre outros aspectos, eventos relacionais e também a teoria do caos, promulgada pela Física Quântica. O título evoca o exemplo utilizado pelos pesquisadores da área para explicar o fenômeno: uma borboleta que bate asas na China pode causar um furacão na América. Assim, a condição inicial de um sistema pode determinar toda uma evolução deste.

Outro filme que traz a configuração em rede, ampliando o conceito para a condição ecológica, é Avatar ${ }^{7}$. Neste, o diretor deixa patente a interrelação entre a natureza e os seres. Quando há rompimento da rede, toda estrutura corre perigo. Capra afirma:

A percepção do mundo vivo como uma rede de relações tornou o pensar em termos de redes - expresso de maneira mais elegante em alemão como vernetztes Denken - outra característica-chave do pensamento sistêmico. Esse "pensamento de rede" influenciou não apenas nossa visão da natureza, mas também a maneira como falamos a respeito do conhecimento científico (CAPRA, 1996, p. 37).

Atualmente, as redes virtuais permitem um campo expandido nunca antes imaginado e vale ressaltar que o funcionamento em rede nessa amplitude não invalida a teoria basilar: da mesma forma, a ação efetuada em determinado ponto da malha atinge outros que estão conectados a ela, como. Assim acontece com eventos isolados que, quando divulgados em redes

\footnotetext{
${ }^{6}$ Efeito borboleta (2004) é uma produção do cinema estadunidense dirigida por Eric Bress e J. Mackye Gruber. Gênero ficção.

${ }^{7}$ Avatar (2009) uma produção do cinema estadunidense, dirigida por James Cameron. Gênero: ficção científica.
} 
sociais, tomam grandes proporções, podendo alcançar todo o planeta. Dessa forma, podemos afirmar que estamos interligados pela existência e esta se apresenta complexa em significados e significantes. Entretanto, se a malha é constituída por ações idênticas, determinadas por uma hierarquia, não temos a diversidade que enriquece e amplifica ao compor, mas a solidificação da forma não reflexiva, que pode reiterar equívocos e estagnar a vida.

Poderá a arte, esta eterna mediadora entre o homem e a poética do existir, por meio da criação reflexiva, estabelecer na matéria o que previamente é percepção, modificando a malha estancada, de forma a permitir uma constante fruição que leva a um denominador crítico, estético e de substância?

\section{Imagens vivas e narrativas}

Em um evento fotográfico-solidário realizado na cidade de Itu, estado de São Paulo, foi solicitado às pessoas que levassem suas fotografias até uma das praças, para exposição em um varal coletivo. Alocadas em um saco plástico e presas por um grampeador, elas convidavam os passantes a uma visita poética. Imagens de todos os gêneros evocando identidades e memórias. Ventos locais que arejavam as condições internas. Sorrisos, olhares longínquos, saudade. Cada qual reagindo conforme suas experiências e olhar.

As imagens, testemunhas de uma realidade poética, não voltariam ao dono, mas seriam trocadas entre os participantes.

No final do evento, algumas ainda hasteavam suas verdades e a praça esvaziou. Então, um morador de rua pergunta a um dos organizadores se pode pegar uma das fotografias que foram abandonadas. Abandono buscando aconchegar o que foi abandonado. Facetas que fazem da realidade um aporte para viver. Recebendo uma resposta afirmativa, ele se dirige ao varal, observa cada uma das imagens com cuidado e finalmente escolhe a de um cachorro. Cachorroidentidade. Imagem-identidade. Companhia-identidade. Cartografia arquetípica. Realidaderepresentação-identidade. Coisa viva, segundo Bateson apud Samain:

No decorrer de minha existência coloquei as descrições de tijolos e de jarras, de bolas de sinuca e de galáxias numa caixinha e, ali, deixei-as repousar em paz. Numa outra caixa, coloquei coisas vivas: os caranguejos do mar, os homens, os problemas de beleza e as questões de diferenças [...]." Colocarei, assim, as imagens (todas as imagens) ao lado dos caranguejos do mar e das borboletas, isto é, na caixa das coisas vivas. [...] não procurarei saber a que servem as imagens e por que existem, e sim como elas existem, como vivem, como nos fazem viver. Ou ainda, quais suas maneiras de nos fazer pensar? $\mathrm{E}$ chegar, desse modo, a desvendar algo da maneira como a imagem nos provoca a pensar, nos convoca a pensar (SAMAIN, 2012, p. 21).

A imagem de um morador de rua rodeado de cães não é rara e faz parte do imaginário e repertório de muitas pessoas. Para alguns, é impensável alguém nessas condições não ter ao menos uma demonstração de acolhida, como a que é evidenciada pelos fiéis animais que, muitas vezes sem alimento suficiente, se recusam a abandonar aquele que está também faminto. Fomes unidas. Degradação de nossa contemporaneidade? Talvez. Mas reside nessa imagem a poética da resistência, das possibilidades reconfortantes geradas no mínimo. Da solidariedade. Configuração da realidade que, pela beleza da dor, ensina e vai às profundezas do ser pela forma. De acordo com Samain (2012, p. 32): 
Anotei, anos atrás, uma frase visionária de Eugênio Ionescu, pois me tinha tocado profundamente. Nem hoje sei por que e onde me tocou. Sem dúvida porque me perturbava num lugar de uma procura profunda que não cheguei ainda a descobrir. Ionescu escreve: "A forma é a corda mais retesa do sentido". A forma é uma espécie de fio, de linha, de linha ou de ligação, que conduz ou direciona o sentido de uma maneira densa, tensa e precisa. Nunca se desliga, se desamarra dos sentidos, das significações, isto é, do pensamento. (SAMAIN, 2012, p. 32)

A imagem do morador de rua acolhendo a fotografia do cachorro gerou uma imagem de outra natureza, a natureza observável, para os espectadores que presenciaram a cena, significando pela poesia. A fotografia não seria a mesma sem a ação do ato de apropriação por aquela pessoa.

Para muitos, a imagem pertence à ordem do efêmero, do acidental, à ordem do fugaz e do frágil. Ela pode ser bela e bonita. É efêmera e de certo modo evanescente. Está sempre de passagem, da ordem da passagem do tempo. Representa um instante de fluxo - e refluxo - de realidade que a faz transbordar em dois movimentos - de dentro para fora e de fora para dentro (SAMAIN, 2012, p. 32).

Este trânsito significativo não tem fixidez, mas é movimento constante e se estabelece na relação público e imagem. A mesma fotografia pode gerar inúmeras respostas dos sentidos, em cada tempo, em cada existência.

[...] como a borboleta que rompe sua crisálida -, a imagem estoura, cintila por um breve instante, antes de levantar voo, de desaparecer momentaneamente. Ela parte. Ela se dissolverá talvez ou será esquecida, dentro de seu tempo histórico. Nunca, todavia, se perderá. Quando a reencontrarmos, dez ou mil anos mais tarde, quando ela se reapresentará a outros olhares - longe do momento inaugural que a tinha feito nascer antes de levantar voo -, a imagem não será mais a mesma. Sob outra forma, carregará, no entanto, a memória de um passado que a atualizará e a ritualizará novamente (SAMAIN, 2012, p. 34).

Portanto, pensar imagens é percorrer trajetórias e cartografias não apenas geográficas, mas também internas e significativas. Rito que não se esgota no simples exercício de detecção, mas se amplia na ação do perceber e transformar por meio de narrativas.

\section{A ludicidade e o sentido de comunidade}

Duarte Júnior (2004) chama a atenção do leitor para o fato de que as relações humanas na contemporaneidade estão cada dia mais esgarçadas. O sistema vigente que, com demandas cada vez maiores e aceleradas oprime o corpo e o trânsito relacional e saudável entre pessoas, gera um grande vazio existencial em que estão imersas muitas camadas da população. O indivíduo, cada dia mais isolado do outro, perde o sentido de alteridade, desencadeando uma sensação de solidão, embrutecimento dos sentidos e egoísmo. São observáveis situações de radicalidade extrema, onde as pseudoverdades absolutas tendem a procurar seu lugar a partir do individualismo e não da coletividade e das trocas. Segundo Bauman (2003) adotamos a sociedade e deixamos de lado a comunidade. De acordo com este, é preciso estar atento ao significado das palavras, pois muitas 
delas evocam sensações. Fruir palavras pode ser um grande jogo de experiências estéticas e significativas. Assim, o autor afirma que a palavra comunidade:

[...] sugere uma coisa boa: o que quer que "comunidade" signifique, é bom "ter uma comunidade," "estar numa comunidade". [...] se alguém se sente miserável, sofre muito e se vê persistentemente privado de uma vida digna, logo acusamos a sociedade - o modo como está organizada e como funciona. As companhias ou a sociedade podem ser más; mas não a comunidade. Comunidade, sentimos, é sempre uma coisa boa. [...]. Para começar, a comunidade é um lugar "cálido", um lugar confortável e aconchegante. É como um teto sob o qual nos abrigamos da chuva pesada, como uma lareira diante da qual esquentamos as mãos num dia gelado. [...] (BAUMAN, 2003, p. 7)

Também os estudos de Ariès (1978) apontam para a importância das manifestações coletivas, nas quais as pessoas se encontravam, independente de idade, para participarem lado a lado de atividades, construindo uma noção de pertencimento. Assim:

A sociedade antiga concentrava um número máximo de gêneros de vida num mínimo de espaço, e aceitava - quando não procurava - a aproximação barroca das condições sociais distantes. A nova sociedade, ao contrário, assegura a cada gênero de vida um espaço reservado, cujas características dominantes devem ser respeitadas: cada pessoa deve parecer com um modelo convencional, com um tipo ideal, nunca se afastando dele, sob pena de excomunhão (ARIÈS, 1978, p. 279).

De acordo com Franco (2012), quando a relação entre as pessoas se dá em uma malha distribuída e não centralizada, ela é uma pessoa comum. Na contemporaneidade, tal termo assume, muitas vezes um caráter pejorativo. Mas o termo comum, originado de comoons:

[...] tem aqui o sentido de commons, de bem comum, de algo compartilhável por uma comunidade (e não de ordinário, normal ou não notável, nem de medíocre, como em geral se atribui pejorativamente). Assim, pessoa comum é aquela que mantém as mesmas condições de compartilhamento das outras pessoas do seu emaranhado, embora cada uma seja, nas suas particularidades, totalmente diferenciada, sempre unique. A pessoa comum é a que compartilha (ela é realmente o que compartilha, ao se deixar varrer pelo sopro, ao ser permeável ao fluxo interativo) e não aquela que alcançou o sucesso em virtude de suas características herdadas (do "sangue" ou do "berço") [...] Ela é alguém que logrou viver a sua convivência, que conseguiu antecipar a plenitude do com-viver ou do viver em rede prefigurando um simbionte social (FRANCO, 2012, p. 77).

Entretanto, na Matrix, geralmente as pessoas não são "comuns (no sentido de commons) e sim pessoas privadas (fechadas à interação com o outro-imprevisível). A Matrix é uma espécie de fábrica de pessoas privadas" (FRANCO, 2012, p. 77).

Mas há uma possibilidade de alienação de 'transeuntidade' para uma situação de 'transeentidade', da Matrix para a Comunidade. Se em estruturas hierárquicas as pessoas tendem a buscar o caráter do incomum e verticalidade para o destaque dos semelhantes, numa proposta coletiva a ideia é buscar uma relação horizontal onde todos possam cooperar num processo colaborativo. 
É possível, pela tomada de consciência, atribuir valores e entender o verdadeiro sentido de alteridade, ao perceber o outro e este em si, respeitando diferenças, numa relação coletiva e saudável.

Considerando o modelo atual, podemos afirmar que o adulto, a cada dia, tem reservado menos tempo para atividades de cunho coletivo, brincante e presencial. Atividades lúdicas que promovam encontros de pessoas são também aquelas que dão à existência humana a dimensão de que cada um é parte de uma coletividade. Estar em comunidade é possibilidade de aprender acerca de diferentes pontos de vista sobre uma mesma situação e estabelecer diálogos profícuos e significativos acerca de si e do outro, compreendendo as partes e o todo que estas geram. De acordo com Santin (1994), no ato brincante, realidades são constituídas. O autor afirma:

A atividade lúdica é uma tessitura simbólica fecundada, gestada e gerada pela criatividade simbolizadora da imaginação de cada um cuja ação se confunde com o brincar. [...] Brincar é, acima de tudo, exercer o poder criativo do imaginário humano construindo o universo real de quem brinca (SANTIN, 1994, p. 28).

Huizinga apontou a importância do jogo na constituição da coletividade. Segundo ele "o objeto de nosso estudo é o jogo como forma específica de atividade, como "forma significante", como função social (HUIZINGA, 2014, p. 7).

Infelizmente a maioria da população adulta de nossos dias não encontra espaço para atividades lúdicas que determinem significados e importância em suas vidas. Dessa forma, "foram ficando cada vez mais reservadas às crianças, cujo repertório de brincadeiras surge então como repositório de manifestações coletivas abandonadas pela sociedade dos adultos e dessacralizadas (ARIÈS, 1978, p. 89).

Esses jogos, que permitiam uma expressão da comunidade em comunidade, são cada dia mais raros. Entretanto, algumas propostas de arte têm adotado características próprias desses territórios, fazendo um traslado de espaços com mantenimento de espírito coletivo e solidário.

\section{Considerações}

O projeto "Imágenes Viajeras", numa proposta coletiva que gerou diversas narrativas visuais a partir de fotografias dos artistas Carmen Molina e Alfonso Infantes, objetivou ampliar a percepção a partir de, primeiramente, reproduções de imagens fotográficas, seguidas por vestígios impressos nestas por outros. Diálogo entre artista, vida e público coautor. Canton afirma:

Diferentemente da tradição do novo, que engendrou experiências que tomaram corpo a partir do séc. XX com as vanguardas, a arte contemporânea que surge na continuidade da era moderna se materializa a partir de uma negociação constante entre arte e vida, vida e arte (CANTON, 2009c, p. 49).

Os relatos dos grupos foram de extrema importância e a verbalização no ato de intervir dos participantes denotam a diversidade e a significação que os elementos visuais trouxeram à memória a partir, muitas vezes, de experiências prévias, em um ato de tomada de consciência na ação relacional com o objeto.

Note-se bem que estou tentando mostrar aqui a existência de uma tomada de consciência que é característica da percepção como sendo um direcionar-se para os objetos. Tenho consciência de algo e, então, realizo um ato de consciência. O Ser Humano, neste caso, está num estado de "Ego acordado", 
quando está na sua corrente de experiências, isto é, num estado de agitação do pensamento, de refletir etc. (SILVA, 1981, p. 25).

As imagens levadas às pessoas apresentam, para além da temática "Caminhos", alguns elementos que suscitam e estimulam o rememorar. Assim, uma menina com mochila nas costas, sozinha, caminhando na direção de uma cidade, cujas fábricas sustentam torres que expelem fumaça; uma cadeira ao lado de uma árvore, numa trilha; pássaros que sobrevoam uma paisagem marítima; a entrada de uma floresta; um contorno de uma pessoa que caminha pela estrada com neblina; uma ponte; um trilho de trem etc. são signos arquetípicos. Seja em forma de metáfora ou de uma situação realmente vivida em algum dos ambientes retratados, o potencial gerador de histórias foi amplamente observado nos grupos. Harari afirma que os

Animais como os lobos e os chimpanzés vivem numa realidade dupla. Por um lado, estão familiarizados com entidades objetivas externas, como árvores, rochas e rios. Por outro, estão cientes de experiências subjetivas que ocorrem dentro deles, como medo, satisfação e desejo. Os Sapiens, em contrapartida, vivem numa realidade com três camadas. Em acréscimo a árvores, rios, medos e desejos, o mundo Sapiens também contém histórias sobre dinheiro, deuses, nações e corporações. [...] Os humanos pensam que fazem história, mas a história comumente gira em torno da teia de histórias ficcionais (HARARI, 2016, p. 163).

Nesse processo de entrelaçamento de intervenções, de traslados poéticos e reflexivos, foi gerada uma rede de existências que coabitam a imagem. Vale ressaltar que as modificações realizadas em uma área causavam uma modificação no conjunto. Narrativas surgiam a cada intervenção, gerando movimentos, fluxos e a procura por estabelecer aspectos identitários com o visto, além da inserção de elementos pessoais ou significativos na imagem. Zumthor (2005) ensina que:

Atualmente, é verdade que algumas pessoas negam isso, mas, da minha parte, estou profundamente convencido de que a história se conta, da mesma forma que os sonhos só existem verdadeiramente quando narrados. [...] Somos seres de narrativa, tanto quanto de linguagem. À medida que me atribuo a tarefa de reter um pedaço do real passado, minha tentativa é, em si mesma, ficção. Se formo um discurso ficcional, para comunicar o resultado, ele será necessariamente narração, quaisquer que sejam talvez minhas precauções estilísticas visando à nudez do relato (Zumthor, 2005, p. 48).

Em diversas ocasiões as pessoas demonstraram receio ao tocar o trabalho realizado por outro, muitas vezes desconhecido, buscando espaços livres. Também aconteceram situações nas quais não houve constrangimento em modificar aquilo que já recebera uma intervenção anterior. Sempre, entretanto, aconteceram momentos de pausa para análise da imagem, para reconhecimento. Alguns fizeram a tentativa de não agredir e procuraram um ‘estilo' que dialogasse com o já existente. Outros tiveram a intenção proposital de modificar completamente.

Este projeto, como citado anteriormente, não teve um público-alvo determinado, fato que trouxe uma rica diversidade de pessoas, de áreas e profissões distintas. Não raro, as pessoas expressavam a frase "não sei desenhar" ou "isso deveria ser feito por artistas", que corrobora com os estudos de Moreira:

Muito depressa o desenho-fala se cala, e do desenho-certeza se passa à certeza de não saber desenhar. É muito comum ouvirmos crianças de menos de 10 
anos dizerem que não sabem desenhar. Em poucos anos, o que era uma certeza, algo tão inquestionável como correr ou jogar bola, parece algo inacessível, próprio apenas de artistas (MOREIRA, 2005, p. 51).

Também ocorreram situações nas quais as pessoas expressavam sua inabilidade com o desenho ou se divertiam ao ver o colega reclamar da intervenção realizada sobre a sua. Nesses momentos, muitas vezes afirmaram, entre risos, que aquelas situações eram próprias de crianças. Vale considerar que "se nesta sociedade o adulto perdeu suas possibilidades de expressão, os jogos, assim como o desenho, passam a ser considerados manifestações infantis. (MOREIRA, 2005, p. 55). Um território onde determinados tipos de expressão são considerados pertinentes apenas quando provenientes de crianças é um mundo limitante e castrador, que determina faixa etária para a experiência do brincar. Vale lembrar que, de acordo com Huizinga (2014), o jogo é basilar na construção cultural. E para além da concepção cultural, o ato de brincar é salutar corporalmente e saudável no cotidiano, por sua condição relacional e coletiva.

Após as atividades, foram realizadas exposições dos trabalhos para os grupos, ao lado da imagem original. Muitos ficaram surpresos ao identificar os caminhos percorridos e resultados finais e inusitados apresentados.

Assim, podemos dizer que "a arte é a linguagem das sensações, que faz entrar nas palavras, nas cores, nos sons ou nas pedras" (DELEUZE E GUATTARI, 1992, p. 228), promotora de reflexões e transformação.

\section{Referências}

ARIÈS, Philippe. História Social da criança e da família. Rio de Janeiro: Zahar, 1978.

AUGÉ, Marc. Não-Lugares: Introdução a uma antropologia da supermodernidade. São Paulo: Papirus, 1994.

BAUMAN, Zigmunt. Comunidade: a busca por segurança no mundo. Rio de Janeiro: Jorge Zahar, 2003.

CALVINO, Ítalo. Um general na biblioteca. São Paulo: Companhia das Letras, 2001.

CANTON, Kátia. Do moderno ao contemporâneo. São Paulo: Martins Fontes, 2009c.

CANTON, Kátia. Narrativas Enviesadas. São Paulo: Martins Fontes, 2009a.

CANTON, Kátia. Tempo e Memória. São Paulo: Martins Fontes, 2009b.

CAPRA, Fritjof. Uma nova compreensão científica dos sistemas vivos. São Paulo: Cultrix, 1996.

DELEUZE, Gilles; GUATTARI, Félix. O que é a filosofia? Rio de Janeiro: Editora 34, 1992.

DUARTE JÚNIOR, João Francisco. O sentido dos sentidos. Curitiba: Criar edições, 2004.

FRANCO, Augusto de. Hierarquia: Explorações de Augusto de Franco em A Matrix Realmente Existente. São Paulo, 2012. 
HARARI, Yuval Noah. Homo Deus: uma breve história do amanhã. São Paulo: Companhia das Letras, 2016.

HUIZINGA, Johan. Homo Ludens. São Paulo: Perspectiva, 2014.

LINS, Daniel. Nietzsche: vida nômade - estadia sem lugar. In: MARQUES, Davina; GIRARDI, Gisele; OLIVEIRA JÚNIOR, Wenceslao Machado de (Org.). Conexões: Deleuze e territórios e fugas e... Petrópolis, RJ: De Petrus et Alii; Campinas, SP: ALB; Brasília, DF: CAPES, 2014.

MOREIRA, Ana Angelica Albano. O espaço do desenho: a educação do educador. São Paulo: Edições Loyola, 2005.

PEREIRA, Lúcia Helena. Bioexpressão. Curitiba: CRV, 2011.

SAMAIN, Etienne. Como pensam as imagens? Campinas: Editora da Unicamp, 2012.

SANTIN, Silvino. Educação física: da opressão do rendimento à alegria do lúdico. Porto Alegre: Edições EST/ESEF, 1994.

SILVA, Ezequiel Theodoro da. $O$ ato de ler: fundamentos psicológicos para uma nova pedagogia da leitura. São Paulo: Cortez, 1981.

ZUMTHOR, Paul. Escritura e Nomadismo: Entrevistas e Ensaios. Tradução de Jerusa Pires Ferreira e Sonia Queiroz. Cotia: Ateliê Editorial, 2005. 